\title{
EVIDENCE FOR THE FORMER EXISTENCE OF A THICKER ICE SHEET ON THE VESTFJELLA NUNATAKS IN WESTERN DRONNING MAUD LAND, ANTARCTICA
}

\author{
PETRI LINTINEN
}

LINTINEN, PETRI, 1996: Evidence for the former existence of a thicker ice sheet on the Vestfjella nunataks in western Dronning Maud Land, Antarctica. Bull. Geol. Soc. Finland 68, Part 1, 85-98.

Vestfjella $\left(73-74^{\circ} \mathrm{S}, 13-16^{\circ} \mathrm{W}\right)$ is a $130 \mathrm{~km}$ long nunatak range in western Dronning Maud Land in East Antarctica, and its northern and southern ends are situated close to the present ice sheet grounding-line. Striations and lodgement till on nunatak Basen indicate that the northernmost Vestfjella nunataks were formerly covered by a thicker Antarctic ice sheet. Striations on the summit ridge of nunatak Plogen indicate that the minimum change in ice thickness has been $700 \mathrm{~m}$ at the present ice sheet grounding-line. The relatively uniform oldest striation direction on different nunatak summits and the altitude of Plogen, which is less than $200 \mathrm{~m}$ lower than the highest Vestfjella summits, indicates that the whole of Vestfjella may have been covered by an ice sheet.

Oxidation of till surface stones and an increased clay fraction in the upper part of the till layer were the only indications of soil formation on Basen. The unweathered nature of the Basen lodgement till indicate a relatively young age for deglaciation. This conclusion is also supported by age determinations and sedimentological data obtained from Weddell Sea sediments by Norwegian researchers, suggesting that a grounded ice sheet extended to the shelf edge at around $21 \mathrm{ka}$ B.P. However the age of the glaciation which covered Basen and Plogen and the subsequent deglaciation is not based on precise dates and therefore the late Wisconsinan/Weichselian age is only a working hypothesis.

Keywords: glacial geology, ice sheet, nunataks, till, fabric, mineral composition, striations, Quaternary, Vestfjella, Dronning Maud Land, Antarctica.

Petri Lintinen, Mariankatu 18. A 12. 00170 Helsinki, Finland. 


\section{INTRODUCTION}

In coastal areas where the Antarctic ice sheet drains to the sea, the most recent glacial advances have been primarily caused by the lowering of global sea level during Quaternary glaciations (Hollin 1962, Drewry \& Robin 1983, Denton et al. 1986). According to suggested palaeo-ice sheet models, the Antarctic ice sheet was some $600-1200 \mathrm{~m}$ thicker at the present grounding-line during the last ice sheet advance, while the thickness change a few hundred kilometres inland was negligible (Hollin 1962, Stuiver et al. 1981). Dated marine sediments around western Dronning Maud Land indicate that the grounded ice sheet at one time, most probably around $21 \mathrm{ka}$, extended more than 100 $\mathrm{km}$ beyond the present grounding line (Elverhøi 1981). On the basis of occurrences of till and striations Jonsson (1988) stated that the elevation of the ice surface during the last glacial expansion may have been about $400 \mathrm{~m}$ higher than at present in the northern Vestfjella area in western Dronning Maud Land.

The following study describes detailed observations of till properties, striae and erratics from the northernmost Vestfjella nunataks. The great number of striae observations on nunataks Basen and Plogen and the till and soil characteristics studied in test pits dug in Basen contributes to the brief observations of Jonsson (1988). Based on new field evidence a minimum ice thickness for the last ice sheet advance in the vicinity of the present ice sheet grounding-line is suggested and as well as an alternative view on ice flow configuration. The field work was carried out during the Finnish Antarctic Research Programme (FINNARP) expedition to western Dronning Maud Land during the austral summer 1989/90. Some parts of this work have already been published by Lintinen (1991) and Hirvas et al. (1994a,b).

\section{PHYSIOGRAPHY OF THE RESEARCH AREA}

Vestfjella $\left(73-74^{\circ} \mathrm{S}, 13-16^{\circ} \mathrm{W}\right)$ is a $130 \mathrm{~km}$ long basaltic range of nunataks trending nearly par- allel to the coastline (Fig. 1.). Vestfjella is situated approximately $120 \mathrm{~km}$ from the coast and its highest summits are about $1100 \mathrm{~m}$ a.s.l.. The coastal area is occupied by the Riser-Larsenisen ice shelf. The summit of the northernmost nunatak, Basen, is at an altitude of $620 \mathrm{~m}$ a.s.l. and the altitudes of the summits of the nearest nunataks, Plogen and Fossilryggen, are $910 \mathrm{~m}$ and $700 \mathrm{~m}$ a.s.l. respectively. Fossilryggen is the only nunatak in Vestfjella where Permian sedimentary rocks outcrop through the ice. The nunataks Basen and Plogen are located approximately $5 \mathrm{~km}$ from the present ice sheet grounding-line, which is clearly evident as an area of great crevasses. The altitude of the ice sheet surface between Basen and Plogen is about 200 $\mathrm{m}$ a.s.l. The elevation differences between Plogbreen, the small outlet glacier between the nunataks, and the summits of Basen and Plogen are about $400 \mathrm{~m}$ and $700 \mathrm{~m}$ respectively. The elevation difference between Fossilryggen and the ice sheet surface is only a few tens of metres. The western side of Vestfjella is dominated by a local ice dome, Högisen. The flat summit area of Högisen is $900 \mathrm{~m}$ a.s.l., only $200 \mathrm{~m}$ lower than the highest nunataks of Vestfjella. At Ritsherflya on the eastern side of central Vestfjella the surface of the ice sheet is flat and the area forms a local ice divide, from which two outlet glaciers start to channel the ice flux around and through Vestfjella. The larger one, Veststraumen, flows towards the south-west, while the smaller one, Plogbreen, flows between Basen and Plogen to Riser-Larsenisen.

About $150 \mathrm{~km}$ inland from Vestfjella is another range of nunataks, Heimefrontfjella $\left(74-75^{\circ} \mathrm{S}, 10\right.$ $13^{\circ} \mathrm{W}$ ), which also trends parallel to the coastline. This nunatak range is about $150 \mathrm{~km}$ long and the highest summits are at altitudes of $2600-2700 \mathrm{~m}$ a.s.l.. Heimefrontfjella is composed of various gneisses and schists of Precambrian age. On the coastal side of Heimefrontfjella the altitude difference between the ice sheet surface and the summits is greater than in the Vestfjella area. On the eastern (inland) side of Heimefrontfjella the ice sheet surface is at approximately the same altitude as the nunatak summits. Heimefrontfjella is thus acting 
Evidence for the former existence of a thicker ice 87

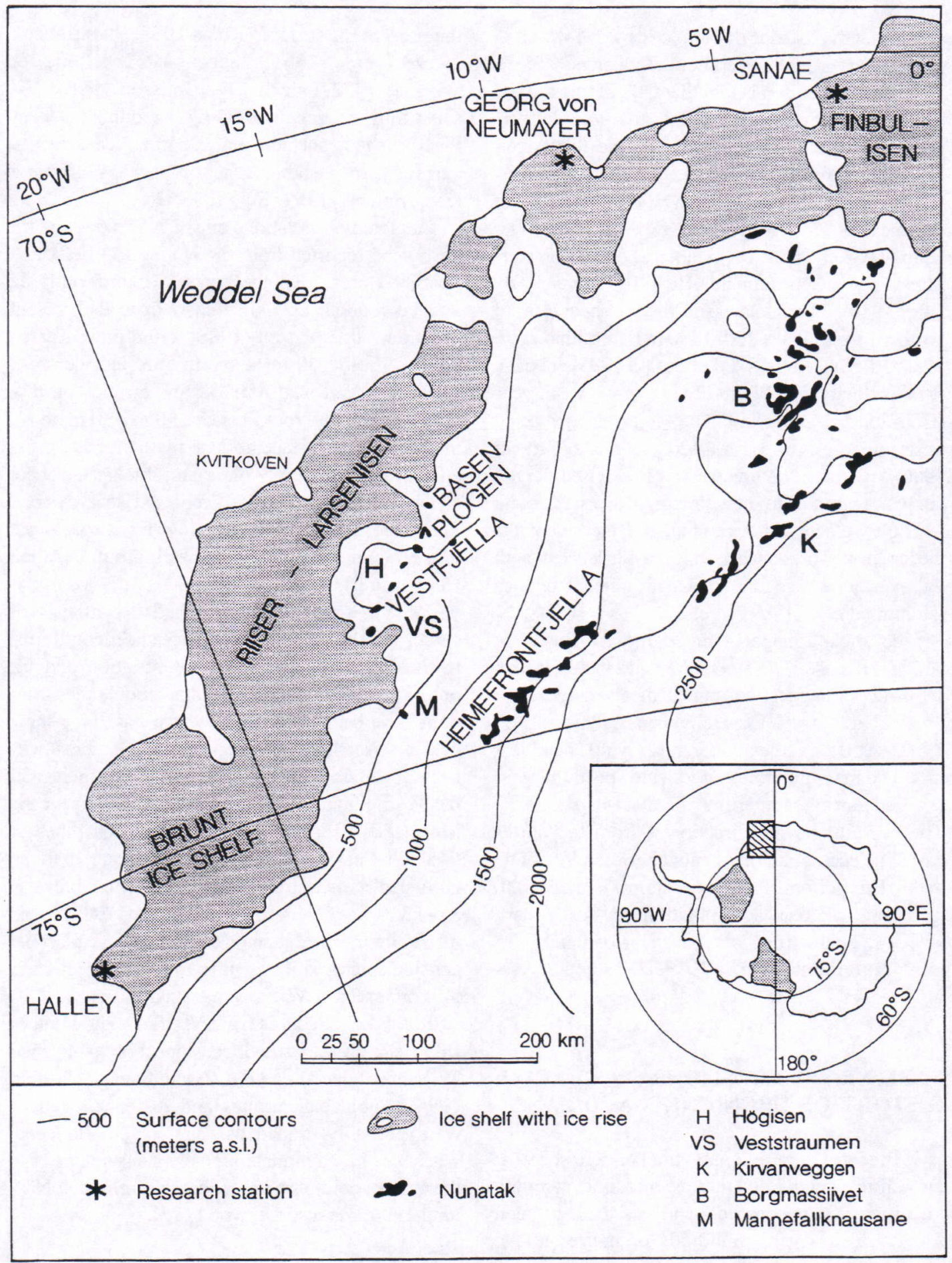

Fig. 1. Western Dronning Maud Land and the main sites referred to in text. 
as an effective barrier or dam to ice flow, which is channelled through several outlet glaciers.

Riiser-Larsenisen is less than $200 \mathrm{~m}$ thick at the ice edge (Orheim 1986), and the ice shelf is grounded locally, as is evident on the Kvitkoven ice rise. The thickness of the ice shelf increases towards the grounding-line where the maximum thickness is $650 \mathrm{~m}$ (Gjessing \& Wold 1986, Orheim 1986). The flow velocity of the RiiserLarsenisen is approximately $120-130 \mathrm{~m} /$ year (Orheim 1986). The thickness of the ice sheet around northern Vestfjella is 200-1000 m (Holmlund et al. 1989, Ruotoistenmäki \& Lehtimäki 1995). The ice flow velocity of Plogbreen is $10-100 \mathrm{~m} /$ year (Holmlund et al. 1989). The larger outlet glacier, Veststraumen, is in places $1200 \mathrm{~m}$ thick (Orheim 1986), whereas the thickness of Högisen is not known. According to snow stratigraphical studies and ice flow velocity and accumulation measurements the ice sheet at present is near its mass balance in both the Vestfjella and the Heimefrontfjella regions (Holmlund et al. 1989).

The mean annual temperature at Basen is $-16^{\circ} \mathrm{C}$ (Taalas et al. 1991). Measurements in firn $10 \mathrm{~m}$ depth suggest an annual mean temperature of $-24^{\circ}$ to $-34^{\circ} \mathrm{C}$ for Heimefrontfjella (Isakson 1992). At Basen, the annual mean wind speed is 7 $\mathrm{m} / \mathrm{s}$. The maximum measured wind speed $(48 \mathrm{~m} / \mathrm{s}$ ) occured during wintertime (Taalas et al. 1991). The prevailing wind direction is from the northeast. The accumulation of snow between Vestfjella and Heimefrontfjella is approximately 30 $\mathrm{mm} / \mathrm{year}$, whereas accumulation on the eastern side of Heimefrontfjella is approximately 15 mm/year (Holmlund et al. 1989, Holmlund \& Näslund 1994).

\section{EARLIER OBSERVATIONS ON GLACIAL HISTORY OF DRONNING MAUD LAND}

Evidence for a previously thicker ice sheet at Dronning Maud Land has been found at many localities where erratics and striae has been found up to several hundreds of metres above the present ice surface (Roots 1953, Swithinbank 1959, Lunde 1961, Juckes 1968, Hjelle \& Winsnes 1972, Patzelt 1988, Jonsson 1988). Observations of lichen growing on nunataks near the ice sheet surface indicate that ice sheet is currently in a stable state or perhaps growing (Swithinbank 1959, Schytt 1961).

Scattered observations on striae, erratics and till have been reported from the Heimefrontfjella and Vestfjella areas. On the central Heimefrontfjella nunataks, about $200 \mathrm{~km}$ inland from the present grounding-line, Patzelt (1988) found unweathered erratics up to $150 \mathrm{~m}$ above the present ice sheet surface. Patzelt also found a few erratics on distinctly weathered rock surfaces up to $430 \mathrm{~m}$ above the present ice surface, indicating the former presence of a considerably older and thicker ice sheet at the area. Juckes (1968) reported striated rock mutonnée indicating an ice flow from south-east in the Mannefalknausane, nunatak group between Heimefrontfjella and Vestfjella.

Jonsson (1988) has published a synthesis of earlier ice flow directions and ice sheet conditions in the Vestfjella area based on striation and till observations. According to his model, the striations have been eroded by a warm-based ice sheet of Late Weichselian/Wisconsinan age, the thickness of which was not sufficient to submerge all the Vestfjella nunataks. The age estimation for the last glacial expansion is based on 14C- dates of Weddell Sea sediments, which indicate that the grounded ice sheet extended to the shelf break at around $21 \mathrm{ka}$ (Elverhøi 1981). Jonsson (1988) found till and far-travelled granitic erratics and one glacially abraded outcrop surface with two sets of striations in the northernmost Vestfjella nunatak, Basen.

Radio-echo records from Vestfjella and Heimefrontfjella show a subglacial morphology formed by intense glacial erosion (Holmlund \& Näslund 1994). Subglacial cirques and U-shaped valleys were probably eroded as early as the Pliocene, when wet-based mountain glaciers existed, prior to the present cold-based ice sheet (Holmlund \& Näslund 1994, see also Drewry 1972). 


\section{SUPERFICIAL COVER AND PERMA- FROST FEATURES ON NUNATAK BASEN}

Basen, when seen from the south-east, has a morphology resembling a huge roche moutonnée (Fig. 2.). The western side of Basen is a vertical wall about $400 \mathrm{~m}$ high, while the eastern side slopes more gently. The summit area of Basen is relatively flat. Winds have eroded $20-40 \mathrm{~m}$ deep depressions, windscoops, in the ice sheet at the base of the nunatak on the north, north-east and east sides. At the bottom of the windscoops the ice forms blue ice fields, which are local ablation areas. The biggest blue ice field occurs on the south-western side of Basen, and it is few square $\mathrm{km}$ in size. The area is also occupied by a frozen supraglacial lake which collects meltwaters percolating from Basen.

The main superficial cover on Basen is frost weathered basaltic regolith, which varies from block fields to more fine grained material. The variable nature of the regolith cover results from the varying susceptibility of different kinds of basaltic layers to frost weathering.

The till cover on the top plateau of Basen is extensive (Fig. 3. and 7.), while another considerable till covered area is the plain on the south-eastern slope where the Finnish and Swedish stations Aboa and Wasa are located. Minor till covered areas occur at various other localities on Basen where the bedrock surface has been favourable for lee-side till deposition. The thickness of the till cover is not known but it is more than $0.8 \mathrm{~m}$.

The third superficial cover is a colluvial diamicton, which occurs on the slopes of the nunatak. Stones in colluvial diamicton have a bimodal distribution with respect to angularity. Boulders and stones may be either sharp, angular local basaltic stones, similar to clasts derived from the frost weathered regolith cover or, alternatively, they can be subrounded basaltic and gneiss clasts similar in

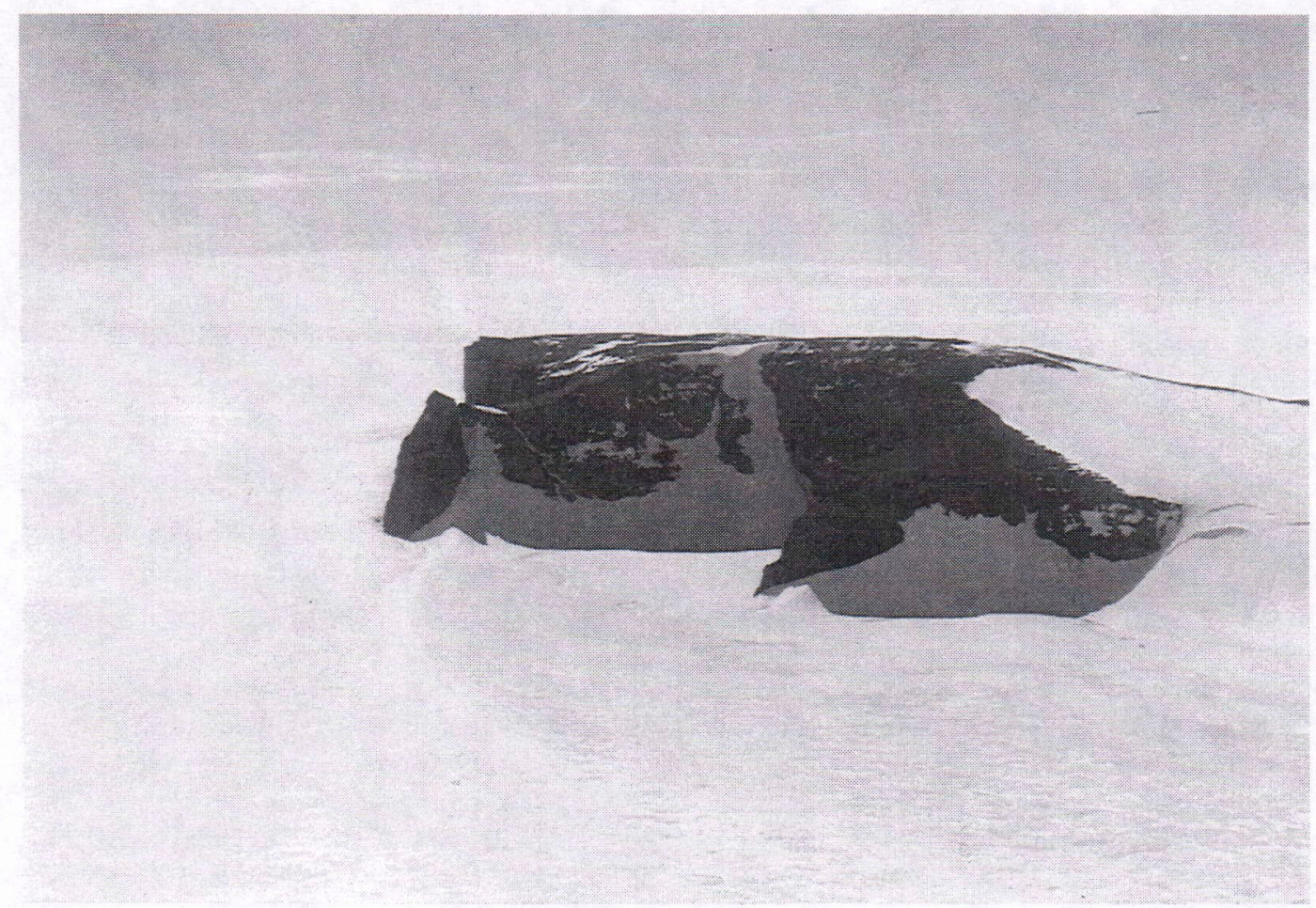

Figure 2. Nunatak Basen seen from the south-east. 


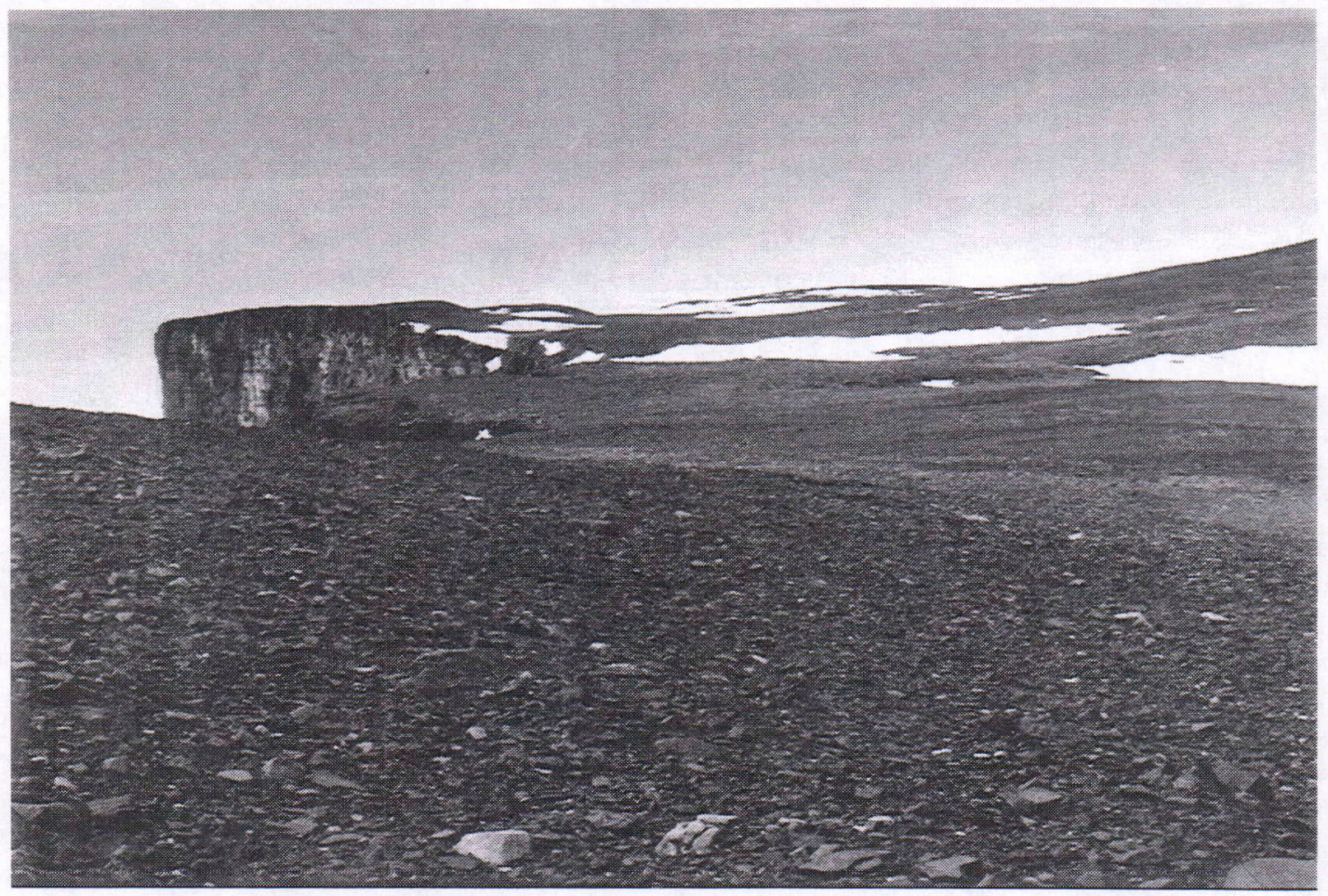

Figure 3. Till cover on the top plateau of nunatak Basen.

shape to common till stones. The colluvial diamicton is evidently a mixture of regolith and till.

Different types of patterned ground have developed on the superficial deposits. Polygons varying in size from $1 \mathrm{~m}$ to $5 \mathrm{~m}$ are present on surfaces sloping less than $5^{\circ}$. Biggest polygons have formed on till surfaces. Slopes $5^{\circ}$ to $10^{\circ}$ exhibit polygons that are nonsorted and elongate in the direction of slope. On steeper slopes elongated polygons grade into stone stripes. On the steepest slopes, where the angle exceeds $20^{\circ}$ the surface morphology is governed by nonsorted steps or shelves which are tens of metres long and around a metre in height.

The permafrost table was found at a depth of $40-70 \mathrm{~cm}$ in test pits excavated in till surfaces. The till on top of permafrost in the active layer was saturated with water in a layer $10-20 \mathrm{~cm}$ thick. Typically the permafrost table consists of massive ice lenses, beneath which the till is dominated by minor ice lenses.

\section{TILL PROPERTIES}

Basaltic clasts were the most prominent rock type in surface stones of tills although sandstones were also abundant on till surfaces. Striated granite and gneiss boulders were occasionally found on till surfaces. Some of the granitic rocks were well rounded, suggesting a fluvial or glaciofluvial origin. Figure 4 is the example of a boulder that even has a percussion mark on its surface. Dark silt- and clay-shale of Fossilryggen type (Hjelle \& Winsnes 1972) was also found occasionally on till surfaces. According to 30 stone counts, the $4-10 \mathrm{~cm}$ fraction of the till contains $10-46 \%$ sandstones, with the remainder being a variety of volcanic rock types that give an indication of the subglacial rock types occurring to the east and south of Basen.

The till surface forms a stone pavement that has been oxidised to various brown rusty colours. The 


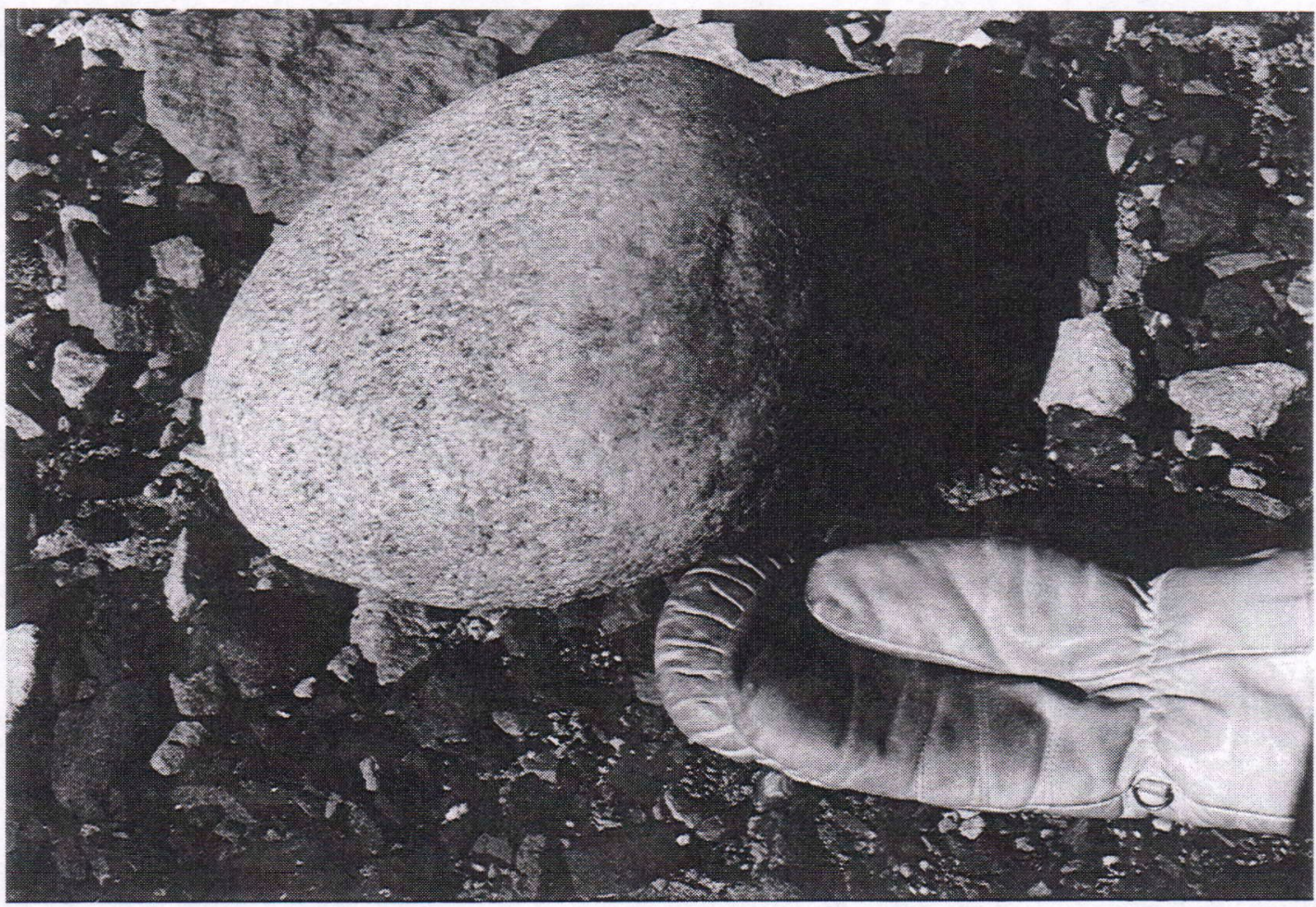

Figure 4. Far travelled gneiss boulder on basal till surface on east flank of Basen, giving an impression of a fluvial or glaciofluvial origin.

superficial stones show only minor signs of polishing by wind. Under the stone pavement the till was rich in clay and fine fractions at a depth of 5-30 $\mathrm{cm}$. The till was massive and structureless. The colour of the till was dark grey and profiles studied show no colour differences related to pedogenesis.

Five clast fabric measurements were performed in test pits in top plateau (three) and south-east plain (two) of Basen. The dip directions of the long axis of 50-100 elongated pebbles were measured at $10-20$ $\mathrm{cm}$ above the permafrost table. The sites were selected to have as little surface gradient as possible to record fabric affected least by solifluction. Four fabric measurements are presented in figure 5. The clast fabric measurements carried out at south-east plain show preferred orientations of $150^{\circ}-190^{\circ}$ which is consistent with the striations in nearby outcrops. Clast fabric measurements from till on top plateau show more variation in preferred directions. The first shows a clear preferred orientation at $70^{\circ}$, whereas the other shows a bimodal orientation with a prominent maximum at $120^{\circ}-130^{\circ}$ and broad weaker maximum at $150^{\circ}-170^{\circ}$. All preferred fabric directions are consistent with striae directions on nearby outcrops. The till on Basen, may be classified as lodgement till because of its massive structure and prominent fabric.

Grain-size analyses from till samples were carried out using hydrometer and wet-sieving methods. The till contains $30-60 \%$ fines $(<0.062 \mathrm{~mm})$ and 5-40 $\%$ clay fraction $(<0.002 \mathrm{~mm})$. The clay fraction content is generally markedly higher in the upper part of active layer than below the permafrost table (Fig. 6.). The vertical variation in clay fraction content in different study pits presumably reflects varying frost weathering conditions in the active layer.

The mineralogical composition of the till clay $(<0.002 \mathrm{~mm})$ fraction was studied by X-ray diffraction analysis using $\mathrm{Ni}$-filtered $\mathrm{Cu}$-radiation. Oriented aggregates were analysed after $\mathrm{K}$ and $\mathrm{Mg}$ 

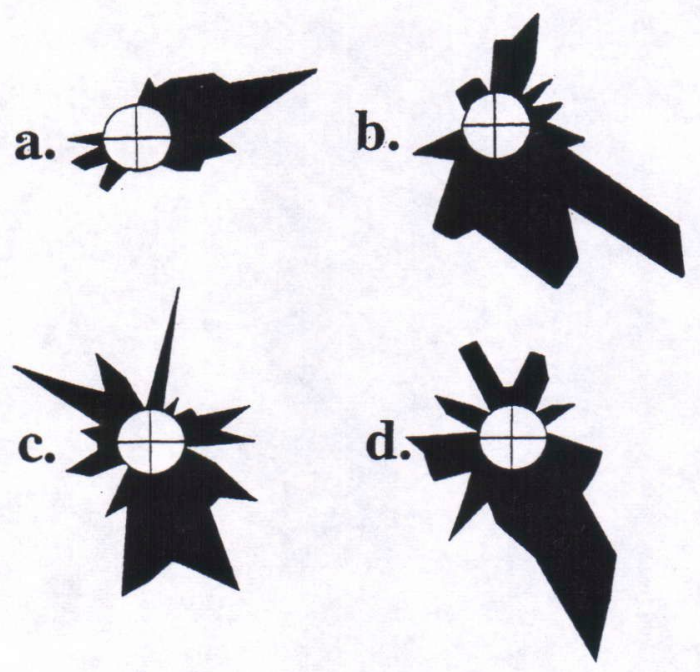

Figure 5. Till clast fabric measurements in test pits on top plateau $(a, b)$ and south-east plain (c, $d)$ of Basen. The dip direction of the long axes of 50-100 elongated pebbles were measured at $10-20 \mathrm{~cm}$ above the permafrost table.

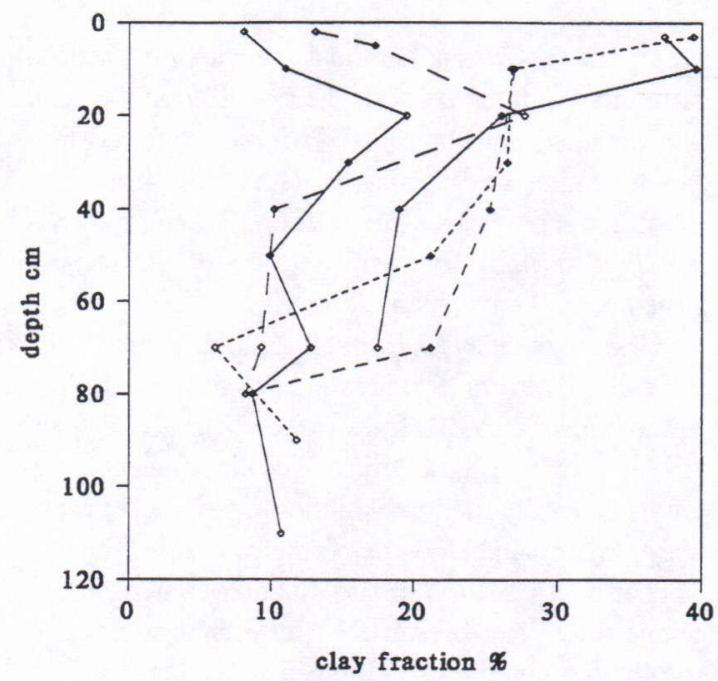

Figure 6. Five examples of the vertical variations of clay fraction content of till samples from different locations at Basen. The lowermost sample in each study site has been taken from below the permafrost table. The clay fraction content was determined using a conventional hydrometer method.
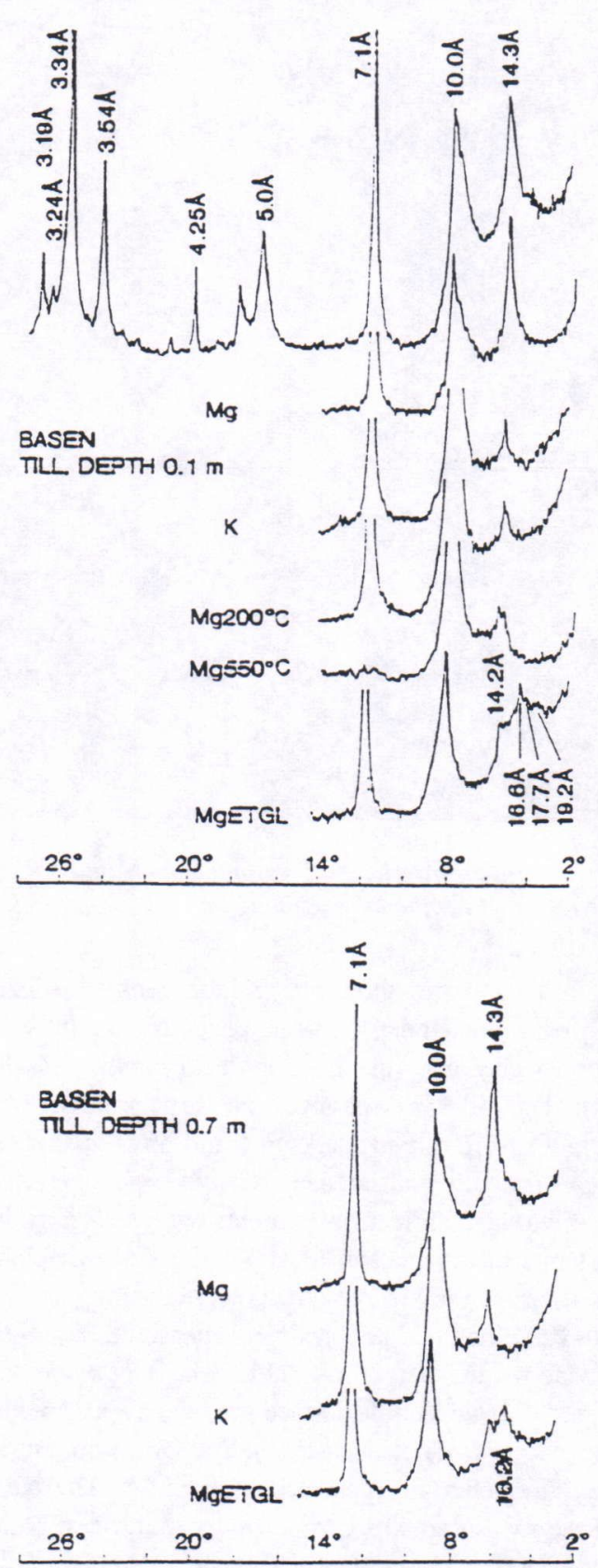

Figure 7. X-ray diffraction traces of oriented aggregates of clay fraction for till samples from Basen. Samples are untreated, $\mathrm{Mg}$ and $\mathrm{K}$ saturated and heated at different temperatures $\left(200^{\circ} \mathrm{C}\right.$ and $\left.550^{\circ} \mathrm{C}\right)$ and treated with etylene glycol (ETGL). The lower sample is taken from below the permafrost table. 
saturation at room temperature and after heating at $200^{\circ} \mathrm{C}$ and $550^{\circ} \mathrm{C}$ temperatures. The clay fraction is composed mainly of kaolinite $(7 \AA, 3.57 \AA)$ illite $(10 \AA)$ and vermiculite $(14 \AA)$. Kaolinite is identified on the basis of $7 \AA$ reflection collapse at $550^{\circ} \mathrm{C}$ temperature and vermiculite on the basis of $14 \AA$ reflection shift to $10 \AA$ when comparing $\mathrm{Mg}$ and $\mathrm{K}$ saturated samples (Wilson 1987 p. 58.). Minor amounts of smectite, mixed-layer vermiculitechlorite, $\mathrm{K}$-feldspar, plagioclase and quartz also occur. X-ray diffraction traces from oriented $<0.002 \mathrm{~mm}$ aggregates with various treatments are shown in Figure 7. No significant difference in clay mineralogy could be detected between samples at a depth of $0.1 \mathrm{~m}$ and a sample from below the permafrost table. According to their mineralogy, the till fines were derived mostly from Permian shales and have not been affected by pedogenesis following deglaciation.

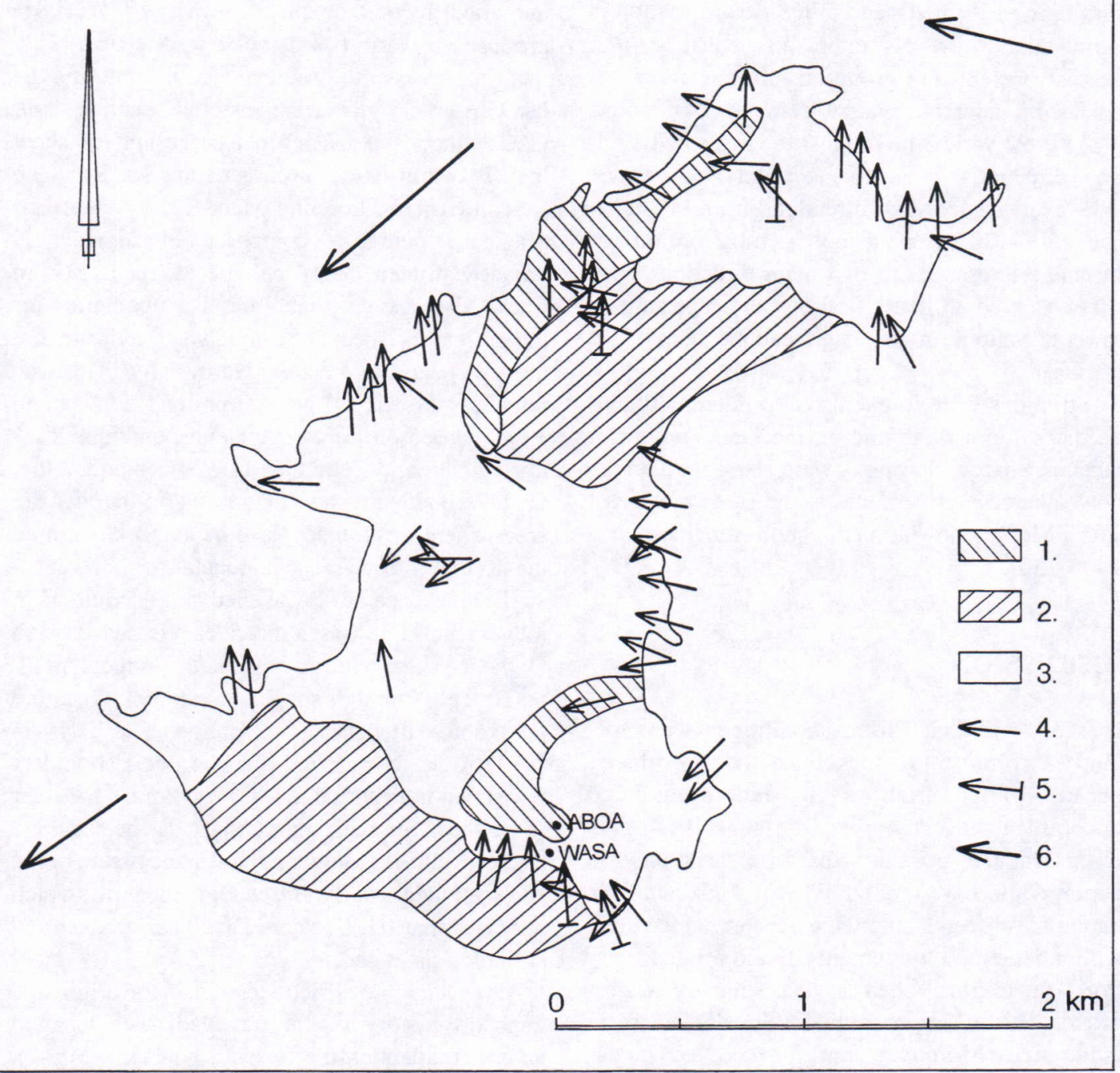

Figure 8. Selected striation observations and distribution of till, snow and regolith cover on nunatak Basen. 1. $=$ till, $2 .=$ snow or glacier ice, $3 .=$ regolith, $4 .=$ striae, $5 .=$ older striae, $6 .=$ present ice flow direction. The locations of the Finnish and Swedish research stations, Aboa and Wasa are also shown. 


\section{GLACIAL STRIATIONS ON BASEN AND PLOGEN}

Striations were found on over 40 unweathered rock surfaces on Basen. Such surfaces were found on the summit edges of the vertical walls and under boulders that had protected the rock surface from temperature differences. Selected striation directions are shown in Figure 8. Although the actual ice flow direction could not be observed directly from roche moutonnée forms, the assumed general ice flow direction is from inland towards either the coast, or the nearest present day grounding-line position.

The main feature evident from the observations is the great variation amongst the measured striation directions, even for adjacent occurrences. Whwever the ice flow directions from $90^{\circ}-110^{\circ}$ and $150^{\circ}-170^{\circ}$ seem to be the most prominent. Striations crossing the two main directions were also observed at many localities and especially at lower elevations on the eastern and southern flanks of Basen.

Striations were found also at different altitudes on the summit ridge and on the main summit of nunatak Plogen. Striations were also found on the unweathered rock surfaces at the steep north-east slope. Measured striation directions range between $140^{\circ}-150^{\circ}$.

\section{DISCUSSION}

It is obvious that Basen and Plogen were formerly covered by a thicker ice sheet or glacier because of the striations that have been found on both nunatak summits. Jonsson (1988) also discussed the possibly that the striations on Basen could have eroded by a local glacier. This explanation seems untenable because an ice mass which deposited lodgement till and eroded striations must have been at least locally warmbased. This is improbable for local glaciers in Antarctica. Moreover, the far-travelled gneiss boulders must have been transported from inland. Jonsson (1988) also suggested that some of the striations on the Vestfjella nunataks could be older than the last ice sheet advance and that they could have been protected by cold-based ice.

Holmlund and Näslund (1994) concluded that the subglacial cirques and U-shaped valleys in the Vestfjella and Heimefrontfjella areas were eroded sometime during the Pliocene when wet-based mountain glaciers existed prior the present coldbased ice sheet. Pressure melting conditions may have still existed, at least locally, favouring glacier erosion and till deposition after the Pliocene. The numerical reconstruction of Stuiver et al. (1981) proposed a warm-based melting zone over wide marginal areas of the Antarctic ice sheet during the last Quaternary glacial expansion. Hasegawa et al. (1992) supposed that even the present ice sheet may be warm-based in parts of the Sør Rondane area in eastern Dronning Maud Land, where supraglacial debris is composed of subglacially abraded striated clasts and the debris is rich in fines. Also, the calculated basal temperatures for the present ice sheet at Vestfjella area indicate that the ice sheet may become warm-based if the ice thickness exeeds $1.1 \mathrm{~km}$ (Holmlund \& Näslund 1994). Based on electromagnetic soundings, Ruotoistenmäki and Lehtimäki (1995) concluded that the present day ice sheet may be warm-based at the areas where ice thickness is more than $1 \mathrm{~km}$ around the northernmost Vestfjella nunataks.

The presence of far-travelled gneiss boulders in lodgement till on Basen indicates effective erosion by the ice sheet which deposited the lodgement till on Basen. Although subglacial bedrock types are not known in detail (e.g. Hungelin \& Thyssen 1991) it can be inferred that the gneiss boulders have been transported at least $100 \mathrm{~km}$ by a glacier or ice sheet. Supraglacial transport can be excluded because of the subangular and striated nature of the gneiss boulders in the Basen lodgement till, which indicates that the boulders have been transported at the ice sheet bed.

It is even more difficult to explain the origin and transport history of far travelled, well-rounded gneiss boulders on the Basen till surface (Fig 4.). Jonsson (1988) noted the glaciofluvial abrasion characteristics of well rounded boulders, but he suggested that they are more likely to be weather- 
ing remnants, corestones, in origin. Evidently these gneiss boulders were deposited as part of the Basen lodgement till cover during the last warm-based ice sheet advance across the northern Vestfjella area. Glaciofluvial sedimentation and erosion have been negligible since the Pliocene, when the Sirius Formation tillite and adjacent gravels were deposited in the Transantarctic Mountains (Mercer 1972, Mayewski 1975, Denton et al. 1984, Barret et al. 1992). It can therefore be assumed that the far travelled gneiss boulders in lodgement till at Basen have had a complex transport history. They may have been eroded and transported by Pliocene glaciers from Heimefrontfjella under wet-based ice conditions and redeposited on Basen during younger ice sheet advances. During the Pliocene glaciofluvial abrasion may have caused the evident roundness and percussion mark on the gneiss boulder in Figure 4. Far travelled gneiss boulders may originate from the period when the subglacial topography was eroded by wet-based Pliocene mountain glaciers (cf. Holmlund \& Näslund 1994). One can also speculate that the well rounded gneiss boulder has simply been eroded from unknown Permian conglomerates near the proximal side of Basen, where the subglacial geology is not well known.

The freshness of the tills, with only oxidised surface stones, indicates that the soil of the Basen till cover belongs to weathering stage 2 in the 1 to 6 soil weathering classification (Campbell \& Claridge 1987). Moreover the mineralogy and the vertical distribution of the clay fraction points to effective physical weathering with no mineralogical changes during soil formation. The freshness of the till indicates that Basen was quite recently exposed to subaerial weathering. Sedimentological observations and radiocarbon dates from Weddell Sea sediments clearly indicate that the ice sheet grounding-line was situated about $150 \mathrm{~km}$ closer to the present coast around 21 ka B.P (Elverhøi 1981). Based on theoretical calculations (Hollin 1962, Stuiver et al. 1981), the ice sheet was 600 $1200 \mathrm{~m}$ thicker at the present grounding-line position during the last glacial expansion. Therefore it is possible that Basen was covered by an ice sheet during the last glacial expansion, during the Late Wisconsinan/Weichselian.

The correspondence between the results of till fabric analyses and striation observations on nearby outcrops leads to the conclusion that both the striations and tills most probably derive from the same ice flow phase. Some of the striations may have been eroded by an ice flow phase older than the last glaciation, and they may have been preserved under cold ice, as speculated by Jonsson (1988). However frost weathering seems to be very active, because fresh rock surfaces are rare at present. Striae eroded by older ice advances may have had little possibility of surviving for an unknown period without having been damaged by frost weathering before the last ice advance covered Basen. It seems most probable that the striations were eroded by the last ice sheet advance.

Jonsson (1988) found one glacially-abraded outcrop on Basen with striae directions of $113^{\circ}$ and $87^{\circ}$. These directions are consistent with the data presented here. Jonsson explains his striation observations on Vestfjella nunataks as reflecting topographically controlled ice flow from Högisen to Veststraumen in southern Vestfjella, and to the Plogbreen in northern Vestfjella during the deglaciation. However, the striations and till fabric measurements from Basen and striations found on the summit of Plogen points to earlier overriding by an ice sheet in a relatively uniform direction over a large area. The striation directions on the Mannefalknausane nunataks, between Heimefrontfjella and Vestfjella (Juckes 1968, Näslund, oral comm. 1994), are also on consistent with the ice flow from inland towards the coast, having an overall trend from south-south-east to north-northwest. Some divergence in striation directions must be assumed because of the subglacial topography of Vestfjella. The relatively uniform oldest striation direction on many nunatak summits and the altitude of Plogen, which is less than $200 \mathrm{~m}$ lower than the highest Vestfjella summits, demonstrates that northern Vestfjella, at least, and probably the whole of Vestfjella were covered by ice sheet.

Many cross striations on Basen top plateau show that easterly $\left(90^{\circ}-110^{\circ}\right)$ ice flow is younger and points towards the present grounding line. In 
addition the striations on the lower flanks of Basen often show directions towards the present grounding line or parallel to the nunatak flanks. Most of the striations found on Basen which do not fit the overall south-south-east to north-north-west direction may be explained by topographically controlled ice flow towards the receding grounding line. The easterly component is seen also in till fabric results, a factor which might be explained by differing degrees of pebble reorientation during younger ice flow.

After overriding the ice thickness decreased, the ice flow directions became more and more dominated by the local Vestfjella topography. When the ice surface was lowered, the Högisen ice dome was separated and Vestfjella started to dam and channel the ice flow to Veststraumen and Plogbreen. This model anticipates at least local basal melting conditions around the subglacial Vestfjella peaks.

\section{CONCLUSIONS}

The striations and the unweathered nature of lodgement tills on Basen indicate that the northernmost Vestfjella nunataks were covered by a thicker East Antarctic ice sheet quite recently. Theoretical models of ice sheet elevations in western Dronning Maud Land during the last Quaternary glacial expansion support the recent age of deglaciation of Vestfjella. According to dated Weddell sea sediments, the last ice sheet advance occurred around 21 ka B.P (Elverhøi
1981). The height difference between the present ice sheet surface and the striated summit of nunatak Plogen is about $700 \mathrm{~m}$, which gives the minimum ice thickness difference at the present grounding-line position. The relatively uniform striation direction on many nunatak summits and the altitude of Plogen, which is less than $200 \mathrm{~m}$ lower than the highest Vestfjella summits, indicates that the whole of Vestfjella may have been covered by an ice sheet.

The recent age of the deglaciation is based on the freshness of the tills, correlation to the dates from Weddel Sea sediments and theoretical models, and not on precise dates at Basen or Plogen. Therefore the recent age of the glacial expansion which covered the northernmost Vestfjella nunataks must be considered a working hypothesis.

ACKNOWLEDGEMENTS: The author thanks the Finnish Antarctic Research Program (FINNARP), Finnish Academy and Kordelin Foundation for financing the study. The logistics were supported by FINNARP through the Finnish Institute of Marine Research. The author thanks the ship crew of RV Aranda and the helicopter pilots for the safe journey to and from Antarctica and in the research area. Special thanks to the whole Finnish group, consisting of eight persons, for a good time at research station Aboa on nunatak Basen. The critical review by Dr. M. Sharp improved the manuscript. 


\section{REFERENCES}

Barret, P.J., Adams, C.J., McIntosch, W.C., Swisher III, C.C. \& Wilson, G.S., 1992. Geochronological evidence supporting Antarctic deglaciation three million years ago. Nature 359, 816-818.

Campbell, I.B. \& Claridge, G.G.C., 1987. Antarctica: soils, weathering processes and environment. Elsevier, Amsterdam, $368 \mathrm{pp}$.

Denton, G.H., Prentice, M.L. Kellogg, D.E. \& Kellogg, T,B., 1984. Late Tertiary history of the Antarctic ice sheet: Evidence from the Dry Valleys. Geology 12, 263-267.

Denton, G.H., Hughes, T.J. \& Karlen, W., 1986. Global ice-sheet system interlocked by sea level. Quaternary Research 26, 3-26.

Drewry, D.J., 1972. Sublacial morphology between the Transantarctic Mountains and the South Pole. In Adie, R.J. (ed.): Antarctic geology and geophysics. Universitetsforlaget, Oslo, 693-704.

Drewry, D.J. \& Robin, G. de Q., 1983. Form and flow of the Antarctic ice sheet during the last million years. In Robin, G. de Q. (ed.): The Climatic Record of Polar Ice Sheets. Cambridge University Press, Cambridge, 28-38.

Elverh $\varnothing$ i, A., 1981. Evidence for a Late Wisconsin glaciation of the Weddell Sea. Nature 293, 641-642.

Gjessing, Y. \& Wold, B., 1986. Absolute movements, mass balance and snow temperatures of the Riiser-Larsen Ice Shelf, Antarctica. Norsk Polarinstitut, Skrifter 187, 23-31.

Hasegawa, H., Iwata, S. \& Matsuoka, N., 1992. Observations of calyey till and underlaying glacier ice in the central Sør Rondane Mountains, East Antarctica. In Yoshida, Y., Kaminuma, K. \& Shiraishi, K. (eds): Recent Progress in Antarctic Earth Science. Terra Scientific Publicing Company, Tokyo, 679-681.

Hirvas, H., Lintinen, P. \& Nenonen, K., 1994a. Moreenin hienoaineksen ominaisuuksista Suomessa ja Etelämantereella. Summary: Properties of till fines in Finland and Antarctica. Acta Universitasis Ouluensis A 251, 24-35.

Hirvas, H., Lintinen, P. \& Nenonen, K., 1994b. Properties of till fines in the Vestfold Hills and Vestfjella areas, Antarctica. Antarctic Reports of Finland 4. 20-27.

Hjelle, A. ja Winsnes, T., 1972. The sedimentary and volcanic sequence of Vestfjella, Dronning Maud Land. In Adie, R.J. (ed.): Antarctic geology and geophysics. Universitetsforlaget, Oslo, 539-546.
Hollin, T.J., 1962. On the glacial history of Antarctica. Journal of Glaciology 4, 173-195.

Holmlund, P., Isaksson, E. \& Karlen, W., 1989. Massbalans, isrörelse och isdynamik: preliminära resultatet från fältsesongen $1988 / 89$ i Vestfjella och Heimefrontfjella, Dronning Maud Land, Antarktis. Stocholms Universitetet, Naturgeografiska institutionen, Raport 73, 66 pp.

Holmlund, P. \& Näslund, J-O., 1994. The glacially sculptured landscape in Dronning Maud Land, Antarctica, formed by wet-based mountain glaciation and not by the present ice sheet. Boreas 23, 139-148.

Hungelin, A. \& Thyssen, F., 1991. Reflection seismic measurements in western Neuschwabenland. In Thompson, M.R.A., Crame, J.A. \& Thomson, J.W. (eds.): Geological Evolution of Antarctica. Cambridge University Press, Cambridge, 73-76.

Isaksson, E., 1992. Spatial and temporal pattern in snow accumulation and oxygen isotopes, western Dronning Maud Land, Antarctica. Department of Physical Geography, Stockholm University, Report 87, 86 pp.

Jonsson, S., 1988. Observations on physical geography and glacial history of the Vestfjella nunataks in western Dronning Maud Land, Antarctica. Naturgeografiska Institutionen, Stockholms Universitet, Raport 68, $57 \mathrm{pp}$.

Juckes, L.M., 1968. The geology of Mannefallknausane and of Vestfjella, Dronning Maud Land. British Antarctic Survey, Bulletin 18, 65-78.

Lintinen, P., 1991. Quaternary Studies on the Northernmost Vestfjella Nunataks, Western Dronning Maud Land, Antarctica. Antarctic Reports of Finland 1. 16-19.

Lunde, T., 1961. On the snow accumulation in Dronning Maud Land. Norsk Polarinstitutt, Skrifter $123,48 \mathrm{pp}$.

Mercer, J.H., 1972. Some Observations on the Glacial Geology of the Beardmore Glacier Area. In Adie, R.J. (ed.): Antarctic geology and geophysics. Universitetsforlaget, Oslo, 427-433.

Mayewski, P.A., 1975. Glacial geology and late Cenozoic history of the Transantarctic Mountains, Antarctica. Institute of Polar Studies, Report 56, $168 \mathrm{pp}$.

Orheim, O., 1986. Flow and thickness of Riiser Larsenisen, Antarctica. Norsk Polarinstitut, Skifter $187,5-22$.

Patzelt, G., 1988. Die geowissenschaftliche expedition in die Kottasberge/Heimefrontfjella und die Kraulberge/ Vestfjella-Glazialmorphologishe Untersuhungen. In Fütterer, D.K. (ed.): Beriche zur Polarforschung 58/88. Alfred-Wegener-Institut für Polar- und Meeresforshung, 183-185. 
Robin, G. de Q., 1988. The Antarctic Ice Sheet, its history and response to sea level and climatic changes over the past 100 million years. Paleogeography, Paleoclimatology, Paleoecology 67, 31-50.

Roots, E.F., 1953. Preliminary note on geology of Western Dronning Maud Land. Norsk Polarinstitutt, Meddedelelser 74, 18-33.

Ruotoistenmäki, T. \& Lehtimäki, J., 1995. Geophysical Ground Measurement on Glaciated Terrain in Queen Maud Land, Antarctica. VII International Symposium on Antarctic Earth Sciences. 10-15 September 1995, Siena, Italy. Abstract.

Schytt, V., 1961. Blue ice-fields, moraine features and glacier fluctuations. Norwegian-British-Swedish Antarctic Expedition 1949-52. Scientific Results IV:E. Norsk Polarinstitutt, Oslo, 24 pp.

Stuiver, M., Denton, G.H., Hughes, T.J. \& Fostook, J.L., 1981. History of the marine ice sheet in West
Antarctica during the last glaciation: A working hypotesis. In Denton, G.H. \& Hughes, T.J. (eds.): The last great ice sheets. John Willey and Sons, New York, 319-436.

Swithinbank, C., 1959. The morphology of the inland ice sheet and nunatak areas of Western Dronning Maud Land. Norwegian-British-Swedish Antarctic Expedition 1949-52. Scientific Results 3 D, Norsk Polarinstitutt, Oslo, $22 \mathrm{pp}$.

Taalas, P., Huovila, S., Karlsson, K. \& Launiainen, J., 1991. Climatology of the Vestfjella Region. FINNARP-89 symposium, 20-22 March, Espoo, Finland. Antarctic Reports of Finland 1, 133-136. Wilson, M.J., 1987. X-ray powder diffraction methods. In Wilson, M., J. (ed.): A handbook of determinative methods in clay mineralogy. Blacie \& Son Ltd., Glasgow and London, 27-99. 